\title{
Egorov S.E.
}

DOI: 10.25108/2304-1730-1749.iolr.2018.56.137-157

\section{Mechanism of application of generally recognized principles and norms on human rights in criminal process of Russia}

\begin{abstract}
Ensuring and protection of the rights and freedoms of citizens are an independent kinds of activity carried out by law enforcers.

Ensuring and protection are the elements of unified mechanism of guarantee of the rights of citizens.

Through ensuring and protection the rights is achieved "real carrying out civil, political, socio-economic and other rights and freedoms", i.e. is achieved realization of generally recognized principle of respect of rights and freedoms of man and citizen.
\end{abstract}

Keywords: human rights; mechanism of application; mechanism of realization; international law; Russian criminal process; Constitution of RF; generally recognized principle and norms on human rights.

In juridical science to separate aspects of application of the norms of international law in criminal process of Russia devoted the works of E.V. Bykova, G.V. Dashkov, V.N. Kudrayvtsev, E.G. Lyakhov, S.A. Lobanov, N.I. Marysheva, Z.A. Nikolaeva, V.P. Panov, N.V. Radushnoyi, K.S. Rodionov and others.

In 1999 V.M. Volzhenkina defended PhD dissertation on topic: "Application of the norms of international law in Russian criminal process". However the accents in this unconditionally interesting work were made by an author on practice of application of the norms of international law, and namely:

\footnotetext{
- Egorov Sergei Evgenyevich - PhD in Law, Associate Professor, a deputy of chief of the Department of Methodic Analytical providing of observance for procedural activity of the bodies of preliminary investigation of the General Prosecutor's Office of Russian Federation, Moscow, Russia. E-mail: mopi_sid@yahoo.com
} 
- an application of foreign legislation in Russian criminal process;

- sending and performing of procedural requests in order of granting legal aid;

- extradition;

- criminal prosecution;

- passing of the exhibits;

- transmitting of the sentenced persons by foreign courts to the country of his state [1, p. 18-21].

In addition, mechanism of application of generally recognized principles and norms, which form the standards of human rights in criminal process of Russia, has not undergone to special research.

Moreover, on remarks of O.A. Chvanov, who studied the general theoretical problems of law enforcement mechanism "consideration of the use of law as a special mechanism has not received sufficient lightning in scientific literature" $[12$, p. 42].

For all that, when consider the problems of criminal process, law enforcement mechanism was not left unattended by scientists. So, in 1993 it was published a monograph of R.Kh. Yakupov "Law enforcement in criminal process of Russia", in which, inter alia, are distinguished and considered the stages of mechanism of law enforcement [13, p. 43-44]. Analyzing the juridical essence of law enforcement mechanism, R.Kh. Yakupov found it necessary to draw attention to the fact that this category is conditional and presents 'mechanism of realization, exercise of the right' [13, p. 41]. We note that mechanism of law enforcement in criminal process is also the mechanism of realization. In this conclusion the scientist does not allow any confusion of ideas. The fact is that one should keep in mind the methodological implications of the provisions of general theory of law, according to which "there are a number of legal norms, especially procedural ones, realization of which is possible only through law enforcement activities" $[12, \mathrm{p}$. 33]. 
In turn, in international public law under implementation is understood "the embodiment of the norms of international law in behavior, activity of states and other subjects, i.e. practical performance of regulatory requirements" [7, p. 131]. Taking into account the specifics of the norms of international law, their performance presupposes an existence of domestic and international implementation mechanisms [7, p. 134].

Taking into account a subject of the research being undertaken, its integral part should be an internal mechanism of implementation. As part of this mechanism, the implementation process presupposes two activities:

- legal and organizational ensuring of performance - law providing law making, control, law enforcement. The result of such activity is legal acts or normative or individual regulation (application);

- direct actual activity on achievement of socially significant results [7, p. 132-133].

It seems that a content of aforementioned domestic mechanism is quite determined but it should be corrected. The fact is that generally recognized principles and norms and works in the basis of these principles and norms, standards of human rights in criminal process are the procedural norms and standards on its nature.

Therefore, it would be right to speak not about domestic mechanism of performance these norms, but about domestic mechanism of their application. This conclusion is based on the results of research of R.Kh. Yakupov and methodological provisions of the general theory of law.

In this case the particularity of mechanism of application of generally recognized principles and norms on human rights (standards of the rights) in criminal process of Russia will be the fact that state in person of a lawmaker will be acted as a subject of legal and organizational ensuring of application. The subjects of direct actual activity on achievement of socially significant results in 
criminal process will be acted the state bodies in person of officials of the bodies of inquiry, preliminary investigation, prosecutor's office and court.

So, lawmaking is the first component of an internal mechanism of applying generally recognized principles and norms on human rights in criminal process in Russia. Its sufficient particularity in the modern stage of legal reform is the fact that in accordance with Constitution of Russian Federation, the rights and freedoms of man and citizen are recognized and guaranteed in compliance with generally recognized principles and norms of international law [3, p. 82]. Wherein an author of the Commentary to Constitution of Russian Federation is indicated in the fact that a lawmaker, determining legal methods and means that guarantees observance of human rights, should take into account the requirements and standards, enshrined in international legal documents [3, p. 83].

Hence, application in lawmaking of human rights standards in criminal process of Russia should be its constituent part.

By virtue of what has been said, the independent task of the study made is a comparative analysis of human rights standards formulated by generally recognized boundaries and norms of international law with human rights guarantees that enshrined by the Russian legislator in the Constitution of Russian Federation and in criminal procedure code of Russian Federation.

The second independent task of the research should be recognized an analysis of particularities of indirect application of generally recognized principles and norms of international law, which form human rights standard in criminal process of Russia. Mechanism of indirect application of the constitutional norms and criminal procedural norms does not include in a subject of study of this article.

A principle to respect rights and freedoms of man is the first generally recognized principles, particularities of which should be analyzed by the Russian lawmaker. 
This principle, as it noted earlier, on its legal nature presents itself a normgoal. Purpose of such norms-goals is to determine main directions of development of society and state, to orientate for legislative activity. As rule, the norms-goals are enshrined in preamble of law [11, p. 95].

Familiarization with an introductory part (preamble) of the Constitution of Russian Federation shows that a number of goals formulated in it, to performance of which a lawmaker seeks. At the same time, the principle to respect human rights and freedoms is not mentioned in the preamble of the Basic Law. The legislator uses a different wording - "asserting human rights and freedoms, civil peace and consent". A law maker uses other formulation - "asserting the rights and freedoms of man, civil peace and consent" [3, p. 11]. In addition, we should not forget that agreed in international arena understanding of the principle to respect the rights and freedoms of man includes an obligation of state to encourage and develop real performance of civil, political, socio-economic and other rights and freedoms [10, p. 24].

Now it is appropriate to note that in the 'Explanatory Dictionary of the Russian Language' the verb 'approve' means "to firmly establish, finally establish, accept, formalize" $[9$, p. 842]. In accordance with the same vocabulary "implement is - to execute, embody into reality" [9, p. 465].

With provision for made interpretation of the verbs 'to approve' and 'to perform' is become obvious that the constitutional goal of asserting the rights and freedoms of man, i.e. a final their establishment, presupposes an embodiment of these rights to reality.

Consequently, a goal of validation of rights and freedoms of man, enshrined in preamble of the Constitution of Russian Federation presupposes the state's obligation to encourage and develop real carrying out the civil, political, socioeconomic and other rights and freedoms. Article 2 of the Constitution of Russian Federation enshrines this obligation: "Man, his rights and freedoms are the highest 
value. Recognition, respect and protection the rights and freedoms of man and citizen are a duty of the state" [3, p. 19].

Thus, generally recognized principle to respect the rights and freedoms of man finds its fixation in the Preamble and Article 2 of the Russian Constitution.

It is noteworthy that at the highest legislative level, a function of protecting human rights is defined as the main guarantee for the exercise of human rights and freedoms.

Provisions of approved on 24 October 1991 by supreme legislative body of Russia the Concept of judicial reform is agreed with these constitutional order. This Concept considers the criminal proceeding as the most important and nonalternative mechanism " $\ldots$ of protection of fundamental rights and lawful interests of citizen in extreme situation of criminal offence" [6, p. 7].

With provision for requirements of the Constitution and the Concept in $1992-$ 2001 in acting that time Code Criminal Procedure of Russia was introduced a number of drastic changes directed on extension of procedural rights of the persons involved in criminal proceeding, and guarantees of these rights. Other words, there were undertaken legislative efforts, which directed in formation of real mechanism of protection the rights and freedoms citizens involved in criminal proceedings. Nevertheless, criminal procedural mechanism of protection did not become as real guarantee of citizens' rights. The data of criminal statistics for period 1997-2001 confirms that. Statistics fixes the absolute growth of number of registered crimes in these years. For instance, it was registered:

1. Crimes against life and health: 1997 - 268780; 1998 -2 74594; 1999 298418; 2000 - 296072; 2001 - 300479.

2. Crimes against freedom, honour and dignity of an individual: 1997 - 8258; 1998 - 12030; 1999 - 18472; 2000 - 18578; 2001 - 15023.

3. Crimes against the constitutional rights and freedoms of man: 1997 - 3471; 1998 - 4760; 1999 - 5307; 2000 - 6105; 2001 - 6354 [2, p. 546-548]. 
It seems that real failure of mechanism of protection the rights of citizens in criminal proceedings that shown by the statistics is determined with a few reasons, and namely:

1. For law enforcers, in particular the officials of the bodies of enquiry and preliminary investigation, the constitutional categories 'man', 'his rights and freedoms, which are the highest value', are perceived like declarative ones.

Conclusion on presence such reason based on the following opinion, said by an authoritative team of the scientists of the Institute of Legislation and Comparative Jurisprudence under the Government of Russian Federation. "Law enforcers, which brought up in conditions of authoritarianism, accustomed to consider the Constitution like something far from their daily activity, like a political declaration, which has no practical significance for them. Act of direct superior managing entity and from common normative acts - the act of their department have a normative significance for practitioners. In the best way they measure their actions with current law, which contains specific norms. Unfortunately, this is concerned also the judges, including the judges of the highest range and the leaders of executive bodies" [4, p. 31].

2. Conceptual fixation of one mechanism of protection as the main guarantee of the rights of man and citizen is wrong. This disorganized the rights and freedoms of man and citizen.

This conclusion made from analysis of the commentary to Article 18 of the Constitution of RF, which prepared by the department of systematization of legislation and legal information of the State legal department of the President of Russian Federation. "Legislative and other normative legal acts of the state, - the commentary determines, - are extremely diverse, and regulate the most diverse spheres of social relations. In such their diversity a priority belongs to the rights and freedoms of man and citizen, which should be acted as main point of legislative and law enforcement practice. The sense and content of the laws, their 
application are verified by the extent to which they correspond to ensuring the rights and freedoms of man and citizen" [5, p. 127].

Consequently, another main goal for law enforcers' activity should be ensuring the rights and freedoms of man and citizens.

The question naturally arises about a content of the legal category 'ensuring'. According to N.V. Vitruk, ensuring of fundamental human rights and freedoms is their guarantee, and as an independent kind of activity, ensuring has the following types:

1. It is carried out in form of activity in various spheres of social life on development of economy, improving of social structure of society, its political system, i.e. in form of activity for the conscious and systematic improvement of the general (economic, social, political) guarantees of the realization of inalienable human rights. The subjects of this kind of activity act the state, all its bodies, other chains of political system, societies (for instance, political parties, public human rights movements).

2. An independent kind of ensuring is a legislative activity of the state to create and improve legal instruments, which are designed to directly ensure the legitimate implementation, and in necessary cases, protection of integral human rights and freedoms.

3. In ensuring activity law enforcement activity of the competent state bodies takes especial place. Law enforcement act adopted during its performing acts as legal fact in process of direct realization rights or freedoms by an individual.

4. Organizational activity those or other subjects of law is a specific kind of ensuring. It directed in effective usage of common and social guarantees in purposes of creation of favourable conditions and organization of the process of realization by an individual his rights and freedoms. Despite the fact that sometimes organizational activity is not embodied in legal forms, it is carried out under the strict observance laws' requirements that related it. 
5. To the sphere of ensuring the rights and freedoms should be attributed preventive activity aimed to prevention of the offences. It assumes detection and elimination of the reasons and conditions that lead to the offences.

6. Educational, informational, consulting and others might be also named as the kinds of ensuring activity [8, p. 12-14].

\section{References}

1. Volzhenkina V.M. Primenenie norm mezhdunarodnogo prava v rossiyiskom ugolovnom protsesse (problem teorii i praktiki) [Application of the norms of international law in criminal process (problems of theory and practice)]. Avtoref. dis... kand. yurid. nauk [Synopsis of thesis of PhD in Law]. Moscow, 1999, 23 p.

2. Dolgova A.I. Prestupnist', eye organizovannost' i kriminal'noe obschestvo [Crime, its organised nature and criminal society]. Moscow, 2003, 572 p.

3. Kommentariyi k Konstitutsii Rossiyisoyi Federatsii [Commentary to the Constitution of Russian Federation]. Pod obsc. red. Yu.V. Kudryavtseva [Ed. by Yu.V. Kudryavtsev]. Moscow, 1996, 552 p.

4. Konstitutsiya, zakon, podzakonnyi akt [Constitution, law, bylaw]. Moscow, 1994, 136 p.

5. Konstitutsiya Rossiyiskoyi Federatsii. Kommentariyi [Constitution of Russian Federation. Commentary]. Pod obsch. red. B.M. Toporina [Ed. by B.M. Toporin]. Moscow, 1994, 246 p.

6. Kontseptsiya sudebnoyi reform $\mathrm{v}$ Rossiyiskoyi Federatsii [Concept of judicial reform in Russian Federation]. Moscow, 1992, 111 p.

7. Mezhdunarodnoe pravo: Uchebnik dlya vuzov [International law: textbook for universities]. Pod red. G.V. Ignatenko [Ed. by G.V. Ignatenko]. Moscow, 1995, $689 \mathrm{p}$. 
8. Obespechenie i okhrana sovetskoyi militsiyeyi konstitutsionnykh prav i svobod grazhdan [Ensuring and protection by soviet militia the constitutional rights and freedoms of citizen]. Moscow, 1988, 80 p.

9. Ozhegov S.I., Shvedova N.Yu. Tolkovyi slovar' russkogo yazyka [Explanatory dictionary of the Russian language]. Moscow, 1999, 944 p.

10. Prava cheloveka. Sbornik universal'nykh I regional'nykh mezhdunarodnykh dokumentov [Human rights. Collection of the universal and regional international documents]. Sost. L.N. Shestakov [Compiled by L.N. Shestakov]. Moscow, 1990, 205 p.

11. Sravnitel'noe konstitutsionnoe pravo [Comparative constitutional law]. Moscow, 1996, $730 \mathrm{p}$.

12. Chvanov O.A. Mekhanizm pravoprimeneniya [Mechanism of law enforcement]. Dis...kand. yurid. nauk [PhD in Law Dissertation]. Saratov, 1995, $238 \mathrm{p}$.

13. Yakupov R.Kh. Pravoprimenenie v ugolovnom protsesse Rossii [Law enforcement in criminal process of Russia]. Moscow, 1993, 195 p. 